\title{
PEMANFAATAN MEDIA AUDIO VISUAL BERBASIS REALISTIC MATHEMATICS EDUCATION (RME) TERHADAP KEMAMPUAN PEMECAHAN MASALAH SISWA MTsS RAUDHATUN NAJAH LANGSA
}

\author{
Saprizal \\ Mahasiswa Pendidikan Matematika IAIN Langsa \\ Email: Saprizalija1972@gmail.com
}

\begin{abstract}
ABSTRAK
Penelitian ini bertujuan untuk mengetahui pengaruh pemanfaatan media audio visual berbasis Realistic Mathematic Education (RME) terhadap kemampuan pemecahan masalah siswa di MTsS Raudhatun Najah Langsa. Metode dalam penelitian ini adalah metode eksperimen kuasi dengan dengan pendekatan kuantitatif, rancangan penelitian ini menggunakan rancangan pretest-posttest control group design. Populasi dalam penelitian ini adalah seluruh siswa kelas VII MTsS Raudhatun Najah Langsa yang berjumlah 96 siswa, sampel dalam penelitian ini dipilih secara random sampling, maka didapat kelas eksperimen adalah kelas VII.a berjumlah 31 siswa dan kelas kontrol adalah kelas VII.b berjumlah 31 siswa. Instrument yang digunakan adalah tes yang berbentuk uraian sebanyak 5 butir soal. Teknik pengumpulan data mengunakan tes kemampuan pemecahan masalah. Hasil pengujian hipotesis yang dilakukan pada taraf signifikan $\alpha=0,05$ dan $\mathrm{dk}=\left(\mathrm{n}_{1}+\mathrm{n}_{2}-2\right)=(31+31-2)=60$ dengan kriteria $-t_{\text {tabel }} \leq$ $\mathrm{t}_{\text {hitnug }}>+t_{\text {tabel }}$ sehingga diperoleh $-2,00 \leq 5,99>+2,00$ sehingga $\mathrm{H}_{0}$ ditolak sehingga dapat disimpulkan bahwa terdapat pengaruh pemanfaatan media audio visual berbasis Realistic Mathematic Education (RME) terhadap kemampuan pemecahan masalah siswa di MTsS Raudhatun Najah Langsa.
\end{abstract}

Kata Kunci: Media Audio Visual, Realistic Mathematics Education (RME),Kemampuan Pemecahan Masalah 


\section{PENDAHULUAN}

Matematika merupakan salah satu mata pelajaran yang ada disetiap jenjang pendidikan mulai dari sekolah dasar hingga perguruan tinggi. Salah satu tujuan diberikannya pelajaran matematika disekolah adalah agar peserta didik memiliki kemampuan memahami konsep matematika, menjelaskan keterkaitan antar konsep dan mengaplikasi konsep atau algoritma, secara luwes, akurat, efisien dan tepat dalam pemecahan masalah. ${ }^{1}$ Oleh karena itu, matematika menjadi ilmu dasar yang harus dikuasai dan memiliki peran penting dalam kehidupan manusia, diantaranya dapat membentuk kemampuan dan keterampilan tertentu untuk pengembangan cara berfikir serta pembentukan sikap. Ruseffendi menyatakan bahwa "matematika penting sebagai pembimbing pola pikir maupun sebagai pembentuk sikap". ${ }^{2}$

Pelajaran matematika merupakan salah satu bidang studi yang menduduki peranan penting dalam pendidikan. Hlm ini dapat dilihat dari waktu, jam pelajaran sekolah lebih banyak daripada pelajaran lain. Tapi, sampai saat ini matematika masih dianggap mata pelajaran yang sulit, membosankan, bahkan menakutkan. Anggapan ini mungkin tidak berlebihan selain mempunyai sifat yang abstrak, matematika juga memerlukan pemahaman konsep yang baik, karena untuk memahami konsep yang baru diperlukan prasyarat pemahaman konsep yang sebelumnya.

Mengingat pentingnya matematika dalam kehidupan sehari-hari, maka siswa diharapkan dapat menguasai matematika terutama pada kemampuan pemecahan masalah. Hlm ini sesuai dengan salah satu tujuan matematika yaitu agar siswa memiliki kemampuan memecahkan masalah yang meliputi kemampuan memahami masalah, merancang model matematika menyelesaikan model dan menafsirkan solusi yang diperoleh. ${ }^{3}$ Kemampuan pemecahan masalah matematis adalah suatu keterampilan pada diri peserta didik agar mampu menggunakan kegiatan matematik untuk memecahkan masalah dalam matematika, masalah dalam ilmu lain, dan masalah dalam kehidupan sehari-hari. ${ }^{4}$

Dalam proses pembelajaran matematika, pemecahan masalah merupakan salah satu faktor yang penting dalam mempengaruhi keberhasilan pembelajaran matematika. Melalui pemecahan masalah siswa dapat memahami masalah dari soal yang ada dengan benar. Selain itu mampu merencanakan dan menyelesaikan cara penyelesaiannya. Siswa diharapkan untuk mampu memecahkan masalah matematika tersebut, sehingga akan berdampak pada ingatan siswa tentang materi pelajaran yang diajarkan. Keterlibatan siswa dalam melakukan langkahlangkah pembelajaran dapat mempertajam ingatan tentang materi pelajaran. Kenyataan dilapangan kemampuan pemecahan masalah siswa dalam belajar matematika belum terlatih dengan baik. Dalam proses pembelajaran siswa hanya menghafal pengetahuan yang diberikan oleh guru dan kurang mampu menggunakan pengetahuan tersebut jika menemui masalah dalam

${ }^{1}$ Sri Wardhani, Analisis SI dan SKL Mata Pelajaran Matematika SMP/MTs untuk Optimalisasi Tujuan Mata Pelajaran Matematika, (Yogyakarta:PPPTKM, 2008) hlm 2.

${ }^{2}$ Ruseffendi, H.E.T., Pengantar Kepada Membantu Guru Mengembangkan Kompetensinya Dalam Pengajaran Matematika Untuk Meningkatkan CBSA, (Bandung:Tarsito, 2006), hlm 1.

${ }^{3}$ Sri Wardhani, Analisis SI dan SKL... hlm 2.

4 Syarifah Fadillah, "Kemampuan Pemecahan Masalah Matematis dalam Pembelajaran Matematika", dalam Prosiding Seminar Nasional Penelitian, Pendidikan dan Penerapan MIPA, 2009, hlm 553. 
kehidupan nyata. Sehingga jika siswa menemui soal yang berkaitan dengan pemecahan masalah, mereka tidak mampu menentukan masalah dan merumuskannya.

Berdasarkan tes kemampuan pemecahan masalah yang diberikan kepada siswa di MTsS Raudhatun Najah Langsa pada tanggal 28 November 2016 diperoleh informasi bahwa kemampuan pemecahan masalah siswa masih tergolong kurang. Sebagian besar siswa mengalami masalah pada saat menyelesaikan soal matematika. Siswa cenderung untuk menggunakan rumus atau cara cepat yang sudah biasa digunakan daripada menggunakan langkah prosedural dari penyelesaian masalah matematika.

Salah satu alternatif untuk meningkatkan kemampuan pemecahan masalah yaitu dengan menggunakan media. Media yang digunakan untuk memperlancar komunikasi dalam proses pembelajaran sering diistilahkan media pembelajaran. Media pembelajaran menempati posisi yang strategis dalam proses pembelajaran karena menjadi perantara informasi pengetahuan dari guru kepada siswanya. Banyak mamfaat yang diberikan media pembelajaran kepada siswa. Sudjana dan Rivai dalam Azhar mengemukakan mamfaat media antara lain: menarik perhatian siswa sehingga dapat menumbuhkan motivasi belajar dan menjadi metode alternatif dalam belajar karena siswa tidak semata-mata mendapatkan pembelajaran dari satu sumber. ${ }^{5}$

Banyak media pembelajaran yang dapat digunakan untuk mendukung pencapaian tujuan pembelajaran. Media tersebut diantaranya media berbasis manusia, cetakan, visual, audio-visual dan komputer ${ }^{6}$. Salah satu media pembelajaran yang efektif untuk kita gunakan adalah media audio visual yang digunakan untuk menyampaikan materi dengan menggunakan mesin-mesin mekanis dan elektronik untuk menyajikan pesan-pesan audio-visual. Media audio visual adalah media yang mempunyai unsur suara dan unsur gambar. Jenis media ini mempunyai kemampuan yang lebih baik, karena meliputi kedua jenis media yang pertama dan kedua. Pengajaran melalui audio-visual jelas dan bercirikan pemakaian perangkat keras selama proses belajar, seperti mesin proyektor film, tape recorder, dan proyektor visual yang lebar.

Media audio visual dapat dirancang sedemikian menarik jika dikaitkan dengan kehidupan nyata siswa sesuai dengan pembelajaran matematika. Pembelajaran yang dapat dikaitkan dengan kehidupan sehari-hari siswa adalah proses belajar mengajar yang menggunakan pendekatan pembelajaran matematika realistik. Soedjadi dalam Turmuzi mengungkapkan bahwa pembelajaran matematika dengan pendekatan realistik adalah pemamfaatan realita dan lingkungan yang dipahami peserta didik untuk memperlancar proses pembelajaran matematika secara lebih baik dari pada masa lalu. ${ }^{7}$ Realita yang dimaksud yaitu hlm-hlm nyata atau konkret yang dapat diamati atau dipahami siswa lewat membayangkan, sedangkan lingkungan yang dimaksud yaitu lingkungan yang berada dalam kehidupan sehari-hari siswa.

Banyak penelitian yang telah dilakukan sebelumnya tentang media dan model pembelajaran matematika realistik, salah satunya penelitian yang dilakukan oleh Abdul Azis

\footnotetext{
5 Azhar Arsyad, Media Pembelajaran, (Jakarta: PT Raja Grafindo Persada, 2007),
} hlm 24.

${ }^{6}$ Ibid.., hlm 81-82.

${ }^{7}$ Muhammad Turmuzi, "Pembelajaran Matematika Realistik Pada Pokok Bahasan Perbandingan di Kelas II SLTP”, dalam Jurnal Kependidikan, No.2 Volume 3.November, hlm 184. 
dengan judul "pengaruh penggunaan media belajar audio visual terhadap hasil belajar siswa mata pelajaran Matematika pada pembahasan dimensi tiga". Dari hasil penelitian diperoleh kesimpulan bahwa ada pengaruh penggunaan media belajar audio visual terhadap hasil belajar siswa mata pelajaran Matematika pada pembahasan dimensi tiga dengan koefisien determinasi sebesar 72,25\%. ${ }^{8}$ Penelitian lain dilakukan oleh Raudatul Husna dkk dengan judul "peningkatan kemampuan pemecahan masalah dan komunikasi matematik melalui pendekatan matematika realistik pada siswa SMP kelas VII Langsa". Dari hasil penelitian menunjukkan bahwa adanya peningkatan kemampuan pemecahan masalah dan komunikasi matematik siswa dengan menggunakan pendekatan matematika realistik lebih tingi dibandingkan dengan siswa yang memperoleh pembelajaran konvensional. ${ }^{9}$

Berdasarkan penelitian relevan diatas dapat disimpulkan media pembelajaran berpengaruh terhadap proses belajar matematika. Oleh karena itu, peneliti melakukan penelitian dengan judul: "Pemanfaatan Media Audio Visual Berbasis Realistic Mathematic Education (RME) Terhadap Kemampuan Pemecahan Masalah Siswa di MTsS Raudhatun Najah Langsa”.

\section{METODE}

Berdasarkan permasalahan yang diteliti, maka penelitian ini menggunakan pendekatan kuantitatif, yaitu penelitian yang banyak menuntut penggunaan angka mulai dari pengumpulan data, penafsiran terhadap data tersebut serta penampilan dari hasilnya. Adapun jenis penelitian ini adalah kuasi eksperimen karena penelitian ini yang diacak bukan siswanya tetapi kelasnya yang diacak.

Penelitian ini menggunakan rancangan penelitian Pretest-posttest Control Group Design. ${ }^{10}$ Rancangan ini menggunakan pembagian dua kelompok penelitian yaitu kelompok penelitian eksperimen dengan menggunakan media audio visual berbasis RME dan kelompok penelitian kontrol menggunakan pembelajaran konvensional yang biasanya digunakan di sekolah sebagaimana digambarkan pada tabel berikut: ${ }^{11}$

\section{Tabel 3.1 Rancangan Penelitian}

\begin{tabular}{|l|c|c|c|}
\hline Kelompok & $\begin{array}{c}\text { Pengukuran } \\
\text { (Pretest) }\end{array}$ & $\begin{array}{c}\text { Perlakua } \\
\mathbf{n}\end{array}$ & $\begin{array}{c}\text { Pengukuran } \\
\text { (Posttest) }\end{array}$ \\
\hline $\begin{array}{l}\text { Eksperime } \\
\text { n }\end{array}$ & $\mathrm{T}_{\mathrm{o}}$ & $\mathrm{X}$ & $\mathrm{T}_{\mathrm{I}}$ \\
\hline Kontrol & $\mathrm{T}_{\mathrm{o}}$ & $\mathrm{Y}$ & $\mathrm{T}_{\mathrm{I}}$ \\
\hline
\end{tabular}

8 Azis, "Pengaruh Penggunaan Media Belajar Audio Visual Terhadap Hasil Belajar Siswa Mata Pelajaran Matematika Pada Pembahasan Dimensi Tiga", Jurusan Pendidikan Matematika, Fakultas Tarbiyah, IAIN Syekh Nurjati Cirebon, 2010, hlm 48.

9 Husna dkk, "peningkatan kemampuan pemecahan masalah dan komunikasi matematik melalui pendekatan matematika realistik pada siswa SMP kelas VII Langsa", Jurnal Pendidikan Matematika PARADIKMA, Vol 6 No 2, hlm 175.

${ }^{10} \mathrm{Ibid}, \mathrm{hlm} .118$

${ }^{11}$ Sukardi, Metodologi Penelitian Pendidikan, (Jakarta: Bumi Aksara, 2008), hlm 185. 
Keterangan:

$\mathrm{T}_{\mathrm{o}}=$ Hasil pretest kelas eksperimen dan kelas kontrol

$\mathrm{T}_{\mathrm{I}}=$ Hasil posttest kelas eksperimen dan kelas kontrol

$\mathrm{X}=$ Menggunakan media audio visual berbasis $R M E$

$\mathrm{Y}=$ Menggunakan Pembelajaran Konvensional

Populasi dalam penelitian ini yaitu seluruh siswa kelas VII di MTsS Raudhatun Najah Langsa Tahun Pelajaran 2016/2017 yang berjumlah tiga kelas, yaitu kelas VII.a, VII.b, VII.c. Pengambilan sampel dalam penelitian ini diambil secara teknik Random Sampling. Random Sampling merupakan teknik pengambilan sampel secara acak. ${ }^{12}$ Dalam pemilihan sampel ini peneliti menggunakan random kelompok yaitu mengacak kelas dari ketiga kelas diatas, karena tidak memungkinkan jika pemilihan sampel menggunakan random subjek. Dari hasil pengambilan sampel didapati kelas VII.a sebagai kelas eksperimen dan kelas VII.b sebagai kelas kontrol.

\section{HASIL DAN PEMBAHASAN}

Data hasil penelitian dikumpulkan terdiri dari data pretest dan postest hasil belajar siswa untuk menjawab rumusan masalah "Apakah terdapat pengaruh pemanfaatan media audio visual berbasis Realistic Mathematic Education (RME) terhadap kemampuan pemecahan masalah siswa di MTsS Raudhatun Najah Langsa”. Berikut akan ditampilkan deskripsi nilai pretest kelas eksperimen dan kelas kontrol pada tabel 4.1:

Tabel 4.1 Rekapitulasi data awal tes awal (pretest) kelas eksperimen dan kelas kontrol

\begin{tabular}{|l|c|c|}
\hline Analisis Data & Kelas Eksperimen & Kelas Kontrol \\
\hline Jumlah siswa (n) & 31 & 31 \\
\hline Rata-rata (mean) & 38.87 & 41.52 \\
\hline Varians & 117.49 & 182.23 \\
\hline Simpangan baku & 10.84 & 13.5 \\
\hline Nilai Tertinggi & 60 & 65 \\
\hline Nilai Terendah & 20 & 20 \\
\hline
\end{tabular}

Tabel 4.1 menunjukkan bahwa rata-rata kelas eksperimen adalah 38,87 dan nilai rata-rata kelas kontrol adalah 41,52. Dari data tersebut didapat selisih 2,65 sehingga dapat dikatakan bahwa kemampuan awal yang hampir sama. Simpangan baku kedua kelas memiliki penyebaran data yang sama yaitu untuk kelas eksperimen adalah 10,84 dan untuk kelas kontrol adalah 13,5. Jadi data yang diperoleh untuk tes awal (pretest) tersebut bervariasi artinya ada nilai yang

${ }^{12}$ Saifuddin Azwar, Metode Penelitian, (Yogyakarta: Pustaka Pelajar, 2005), hlm. 110 
tertinggi dan ada nilai yang terendah. Sehingga dapat disimpulkan data tes awal untuk kelas eksperimen dan kelas kontrol memiliki variabilitas data yang kecil dan bersifat homogenitas. Hlm ini sesuai dengan pendapat Anas Sudijono yaitu: "jika simpangan baku lebih besar, hlm ini berarti makin besarlah variabilitas datanya atau semakin kurang homogen. Sebaliknya apabila simpangan baku kecil, data yang sedang diteliti bersifat homogen". ${ }^{13}$

Setelah dilakukan kegiatan pembelajaran dikelas eksperimen dengan memanfaatkan media audio visual berbasis RME maka dilakukan tes akhir (postest) pada kedua kelas sampel. Berikut akan ditampilkan deskripsi nilai postest kelas eksperimen dan kelas kontrol pada tabel 4.2:

\section{Tabel 4.2 Rekapitulasi data awal tes akhir (postest) kelas eksperimen dan kelas kontrol}

\begin{tabular}{|l|c|c|}
\hline Analisis Data & Kelas Eksperimen & Kelas Kontrol \\
\hline Jumlah siswa (n) & 31 & 31 \\
\hline Rata-rata (mean) & 79.48 & 74.91 \\
\hline Varians & 148.79 & 129.65 \\
\hline Simpangan baku & 12.19 & 11.39 \\
\hline Nilai Tertinggi & 100 & 95 \\
\hline Nilai Terendah & 60 & 50 \\
\hline
\end{tabular}

Berdasarkan tabel 4.2 diperoleh nilai rata-rata kelas eksperimen 79,48 dan nilai rata-rata kelas kontrol 74,91. Nilai rata-rata kedua kelas tersebut memiliki selisih yaitu 4,57 ini berarti kelas eksperimen siswanya banyak memperoleh nilai tinggi dari pada kelas kontrol. Hlm ini terjadi karena guru memberikan perbedaan perlakuan dikedua kelas tersebut. Kelas eksperimen guru menggunakan media audio visual berbasis RME pada kegiatan pembelajaran sehingga diperoleh nilai rata-rata lebih tinggi.

Jika dilihat dari nilai varians dan simpangan baku kedua kelas, diperoleh nilai varians 129,65 dan simpangan baku 11,39 pada kelas kontrol, sedangkan nilai varians 148,79 dan simpangan baku 12,19 pada kelas eksperimen ternyata memiliki selisih sangat kecil yaitu 0,8, maka dapat dilakukan penyebaran data yang sama pada kedua kelas tersebut yang memiliki populasi.

Pengujian normalitas data nilai postest siswa kelas eksperimen dan kelas kontrol adalah dengan menggunakan uji normalitas dan chi kuadrat. Uji normalitas data dari nilai postest kedua kelas tersebut bertujuan untuk melihat data dari setiap kelas dalam penelitian ini berdistribusi normal atau tidak. Hasil perhitungan normalitas data kelas eksperimen pada taraf signifikan $\alpha=0,05$ dan derajat kebebasan $(d k=n-1)=5$, diperoleh $\chi_{\text {hitung }}^{2} \chi_{\text {tabel yaitu untuk kelas }}^{2}$ eksperimen 7,49 < 11,07 sehingga dapat disimpulkan bahwa data hasil postest kelas eksperimen berdistribusi normal.

Selanjutnya uji normalitas data hasil postest untuk kelas kontrol pada taraf signifikan $\alpha=0,05$ dan derajat kebebasan $(d k=n-1)=5$, diperoleh $\chi_{\text {hitung }}^{2} \chi_{\text {tabel yaitu untuk kelas }}^{2}$

${ }^{13}$ Anas Sudijono, Pengantar Statistik Pendidikan, (Jakarta: Raja Grafindo Persada, 2008), hlm 170. 
eksperimen 2,09 < 11,07 sehingga dapat disimpulkan bahwa data hasil postest kelas kontrol berdistribusi normal.

\section{1) Deskripsi Uji Homogenitas Data}

Perhitungan uji homogenitas untuk variabel dari kedua kelas pada nilai postest dapat dilihat pada tabel 4.3 berikut:

Tabel 4.3 Hasil Uji Homogenitas Postest

\begin{tabular}{|l|c|c|c|c|c|c|}
\hline \multirow{2}{*}{ Kelas } & $\bar{x}$ & $\mathbf{S}^{2}$ & $\mathbf{S}$ & \multicolumn{2}{|c|}{ Dk } & \multirow{2}{*}{ F } \\
\cline { 1 - 3 } & & & & Pembilang & Penyebut & \\
\hline Eksperimen & 79,48 & 148,79 & 12,19 & 30 & 30 & \multirow{2}{*}{1,15} \\
\hline Kontrol & 74,91 & 129,65 & 11,39 & & & \\
\hline
\end{tabular}

Berdasarkan tabel 4.3 di atas menunjukkan bahwa pada taraf signifikan $\quad \alpha=0,05$ diperoleh $\mathrm{F}_{\text {hitung }}=1,15$ dan $\mathrm{F}_{\text {tabel }}=1,84$, karena $\mathrm{F}_{\text {hitung }}<\mathrm{F}_{\text {tabel }}$ yaitu $1,15<1,84$, hlm ini berarti bahwa kedua kelas mempunyai varians yang sama (homogen), sehingga sampel yang digunakan dapat mewakili populasi yang ada dan dapat dilanjutkan untuk uji hipotesis.

\section{2) Deskripsi Uji Hipotesis Data (uji t)}

Setelah semua uji prasyarat terselesaikan, maka dilanjutkan dengan uji-t untuk mengetahui pengujian hipotesis. Hasil pengjian hipotesis dapat dilihat pada lampiran 20 (pada hlmaman 108). Pengujian hipotesis dilakukan pada taraf signifikan $\alpha=0,05$ dan derajat kebebasan $\mathrm{dk}=\left(\mathrm{n}_{1}+\mathrm{n}_{2}-2\right)=(31+31-2)=60$ diperoleh nilai $t_{\text {hitung }}=5,99$ dan $t_{\text {tabel }}=2,00$ dengan kriteria pengujian $-t_{\text {tabel }} \leq t_{\text {hitung }}>+t_{\text {tabel }}$, karena $t_{\text {hitung }}>t_{\text {tabel }}$ yaitu 5,99 2,00 maka dapat ditarik kesimpulan bahwa Ho ditolak dan Ha diterima yaitu "Terdapat pengaruh pemanfaatan media audio visual berbasis Realistic Mathematic Education (RME) terhadap kemampuan pemecahan masalah siswa di MTsS Raudhatun Najah Langsa”.

\section{PEMBAHASAN}

Hasil analisis data pretes menunjukkan bahwa kedua kelas sampel (kelas eksperimen dan kelas kontrol) homogen yaitu memiliki kemampuan awal yang sama, sehingga kedua kelas sampel ini dapat digunakan penelitian lebih lanjut. Selanjutnya kedua kelas tersebut diberikan media pembelajaran yang berbeda, yakni kelas eksperimen diberikan pembelajaran dengan memanfaatkan media audio visual berbasis Realistic Mathematic Education (RME) dan di kelas kontrol siswa diajarkan tanpa memanfaatkan media audio visual berbasis Realistic Mathematic Education (RME) pada materi Aritmatika Sosial. 
Hasil pengujian hipotesis yang dilakukan pada taraf signifikan $\alpha=0,05$ dengan derajat kebebasan $\mathrm{dk}=\left(\mathrm{n}_{1}+\mathrm{n}_{2}-2\right)=31+31-2=60$ diperoleh nilai $t_{\text {hitung }}=5,99$ dan $t_{\text {tabel }}=2,00$ dengan kriteria pengujian $-\mathrm{t}_{\text {tabel }} \leq \mathrm{t}_{\text {hitung }}>+\mathrm{t}_{\text {tabel }}$ maka $\mathrm{H}_{0}$ ditolak dan Ha diterima. Sehingga dapat disimpulkan bahwa terdapat pengaruh pemanfaatan media audio visual berbasis Realistic Mathematic Education (RME) terhadap kemampuan pemecahan masalah siswa di MTsS Raudhatun Najah Langsa.

Pemanfaatan media audio visual berbasis Realistic Mathematic Education (RME) ini berpengaruh dalam meningkatkan kemampuan pemecahan masalah siswa di kelas eksperimen, karena dalam memanfaatkan media audio visual berbasis Realistic Mathematic Education (RME) ini pembelajaran akan lebih menarik bagi siswa karena dikaitkan dengan kehidupan nyata sehingga siswa lebih memahami masalah-masalah yang terjadi di kehidupan sehari-hari. Pembelajaran dengan memanfaatkan media ini juga lebih berhasil dibandingkan dengan kelas kontrol yang tidak memanfaatkan media audio visual berbasis Realistic Mathematic Education (RME), dikarenakan pada kelas kontrol pembelajaran lebih mengandalkan daya imajinasi siswa. Setiap siswa mempunyai daya imajinasi yang berbeda-beda dalam memandang suatu permasalahan, inilah yang mengakibatkan pembelajaran yang dikaitkan dengan kehidupan nyata lebih berhasil daripada pembelajaran yang lebih mengandalkan imajinasi.

Hlm ini sejalan dengan teori Ausubel yang mengemukakan teori tentang meaningful learning, reinforcement, low of effect, law of readiness, and law of exercise. Meaningful learning diartikan sebagai belajar bermakna, yaitu belajar dengan melalui tahapan mengetahui, memahami, mengaplikasikan dan memilikinya untuk dimanfaatkan lebih lanjut. Karena belajar dengan cara menghayal dan menghapal saja tidak cukup dan belum bermakna. ${ }^{14}$

Menurut teori Wallace kreativitas merupakan suatu tahap verifikasi, tahap ini merupakan tahap pengujian ide atau kreasi baru terhadap realitas (kenyataan). Disini diperlukan pemikiran divergen dan konvergen. Proses divergensi (pemikiran kreatif) harus diikuti oleh proses konvergensi (pemikiran kritis). Pemanfaatkan media audio visual berbasis Realistic Mathematic Education (RME) yang digunakan pada penelitian ini sifatnya konkrit atau nyata karena proses pembelajaran dikaitkan dengan kehidupan sehari-hari sehingga terjadi proses berfikir yang mengaitkan pengetahuan setiap siswa dan pengalamannya dengan pengetahuan baru yang sedang dipelajarinya, dengan demikian menjadikan siswa lebih kreatif dan inovatif dalam mecapai pengetahuan baru. ${ }^{15}$

\section{KESIMPULAN}

Berdasarkan hasil penelitian yang telah dilaksanakan tentang pemanfaatan media audio visual berbasis Realistic Mathematic Education (RME) terhadap kemampuan pemecahan masalah siswa maka dapat disimpulkan bahwa :"terdapat pengaruh pemanfaatan media audio visual berbasis Realistic Mathematic Education (RME) terhadap kemampuan pemecahan masalah siswa di MTsS Raudhatun Najah Langsa pada materi Aritmatika Sosial. Hlm ini dapat

\footnotetext{
${ }_{14}^{14}$ Slameto, Belajar dan Faktor-faktor yang Mempengaruhi, (Jakarta: Rineka Cipta, 2010), hlm 87.

${ }^{15}$ Munandar Utami, Pengembangan Emosi dan Kreativitas (Jakarta: Rineka Cipta, 2004), hlm 95.
} 
dilihat dari pengujian hipotesis data postest dimana diperoleh $t_{\text {hitung }}>t_{\text {tabel }}$ yaitu 5,99 2,00 sehingga $\mathrm{H}_{0}$ ditolak dan $\mathrm{H}_{\mathrm{a}}$ diterima.

Dari hasil penelitian yang telah dilakukan, peneliti mengajukan beberapa sarankan sebagai masukan adalah sebagai berikut:

1. Bagi guru diharapkan dapat memanfaatan media audio visual berbasis Realistic Mathematics Education (RME) dalam kegiatan belajar mengajar karena dapat meningkatkan kemampuan pemecahan masalah siswa.

2. Bagi siswa diharapkan untuk lebih meningkatkan motivasi belajar serta belajar lebih giat dan tekun agar memperoleh hasil belajar yang baik.

3. Dalam menerapkan media audio visual berbasis Realistic Mathematics Education (RME) diharapkan mampu diaplikasikan tidak hanya pada materi Aritmatika Sosial saja, tetapi juga pada materi matematika lainnya.

4. Dalam menerapkan media audio visual berbasis Realistic Mathematics Education (RME) ini terdapat suatu kekurangan yaitu banyaknya durasi waktu yang diperlukan oleh guru untuk melakukan proses belajar mengajar. Solusi yang bisa ditawarkan yaitu diperlukan persiapan dan perencanaan yang baik khususnya perencanaan/pengelolaan waktu, dalam hlm ini guru harus menyiapkan perangkat pembelajaran dan perlengkapan media audio visual sebelum memulai pembelajaran sehingga seluruh kegiatan pembelajaran dapat berjalan secara optimal dan efisien.

\section{DAFTAR PUSTAKA}

Arsyad, Azhar. 2007. Media Pembelajaran. Jakarta: PT Raja Grafindo Persada.

Azis. 2010. Pengaruh penggunaan media belajar audio visual terhadap hasil belajar siswa mata pelajaran Matematika pada pembahasan dimensi tiga. Jurusan Pendidikan Matematika, Fakultas Tarbiyah, IAIN Syekh Nurjati Cirebon.

Azwar, Saifuddin. 2005. Metode Penelitian. Yogyakarta: Pustaka Pelajar.

Fadillah, Syarifah. 2009. Kemampuan Pemecahan Masalah Matematis dalam Pembelajaran Matematika, dalam Prosiding Seminar Nasional Penelitian. Pendidikan dan Penerapan MIPA

Ruseffendi, H.E.T. 2006. Pengantar Kepada Membantu Guru Mengembangkan Kompetensinya Dalam Pengajaran Matematika Untuk Meningkatkan CBSA. Bandung: Tarsito.

Slameto. 2010. Belajar dan Faktor-faktor yang Mempengaruhi. Jakarta: Rineka Cipta.

Sudijono, Anas. 2008. Pengantar Statistik Pendidikan. Jakarta: Raja Grafindo Persada.

Sukardi. 2008. Metodologi Penelitian Pendidikan. Jakarta: Bumi Aksara.

Turmuzi, Muhammad. Pembelajaran Matematika Realistik Pada Pokok Bahasan Perbandingan di Kelas II SLTP, dalam Jurnal Kependidikan, No.2 Volume 3.November.

Utami, Munandar. 2004. Pengembangan Emosi dan Kreativitas. Jakarta: Rineka Cipta.

Wardhani, Sri. 2008. Analisis SI dan SKL Mata Pelajaran Matematika SMP/MTs untuk Optimalisasi Tujuan Mata Pelajaran Matematika. Yogyakarta: PPPTKM 